\title{
WHAT DETERMINES PROPENSITY TO GET PUBLIC INVESTMENT SUBSIDIES? A CASE STUDY OF THE CZECH FOOD INDUSTRY
}

Jindřich ŠPIČKA, University of Economics, Prague, Faculty of Business Administration, Department of Strategy, W. Churchill Sq. 4, Prague 3, Czech Republic, phone: + 42022409 8351, e-mail: jindrich.spicka@vse.cz.

The aim of the paper is to is to quantify differences in structural and economic indicators between participants and nonparticipants of the investment support programmes in the Czech food industry at the beginning of the old programming period (2007). Resear ch was conducted on a dataset of supported projects from the Ministry of Agriculture and Ministry of Industry and Trade combined with structural and economic indicators of participating and nonparticipating companies provided by MagnusWeb database. Final database contained 1225 companies. However, not all indicators were available for all companies. Original set of variables was selected through Principal Component Analysis. Propensity to be supported was calculated through probit regression. Public investment support has had pretensions to increase productivity of the food industry as well as the added value of agricultural production by supporting many operations in agricultural processing and marketing. Ex-post evaluation of the "old" programming period 2007-14 shows that companies with larger size, lower trade margin, optimal liquidity, lower debt ratio and higher credit debt ratio had higher propensity to be supported. Conclusions about size and credit debt ratio follow previous research by other authors that small companies had lower chance to be supported because of more difficult access to good advisory services and bank loans.

Keywords: investment support, food technologies, impact assessment

\section{INTRODUCTION}

In the European Union, there are structural funds and development programmes to increase competitiveness of various industries. Each country adds its own national sources to co-finance investment projects or provides national investment support for enterprises which are not eligible for support from European funds. Some applicants use advisory services to complete investment projects (Ascione et al., 2011). There are companies which voluntarily do not enter support programs, companies whose submission has been rejected as well as companies which did not meet financial condition to be supported (Kontsevaya et al., 2016; Naglova et al., 2017). The question of the paper is how structural and financial features determine participation in investment support programmes? This is particularly important question for policy makers who set structural and financial criteria for applicants.

The aim of the article is to quantify differences in structural and economic indicators between participants and nonparticipants of the investment support programmes in the Czech food industry. The article investigates the food industry as important industry processing agricultural products and providing food for people and animals. Another reason for food industry is that it receives relatively a lot of money for modernization and innovation from the Rural Development Programme (RDP), Operational Programme (OP) and state budget.

The Czech Republic was selected for a case study of distributional effects of the investment subsidies because of data availability at individual company level. In the period 2007-2013, the RDP provided investment subsidies for small and medium enterprises within two sub-measures: I.1.3.1 Adding value to agricultural and food products, and I.1.3.2 Cooperation for development of new products, processes and technologies (or innovations) in food industry. The national support programme No. 13 (Decree of the Ministry of Agriculture) supported large food processing enterprises. The RDP measure I.1.3 granted for tangible and intangible investments concerning processing and/or marketing and/or the development of new products, processes and technologies linked to products, covered by Annex I to the EC Treaty (except fishery products), and respecting the EC standards applicable to the investment concerned. Moreover, some branches of the food industry not covered by the Ministry of Agriculture (like bakery or beer production) were supported from Operational Programme of the Ministry of Industry and Trade. All programmes, mutually not rival, aimed at modernization of equipment and technological innovations. Recent technologies, innovations and modernisation are frequently well-thought-out as important drivers of economic growth in all countries (Hodrab et al., 2016).

Copyright (C) 2017 The Authors. Published by Aleksandras Stulginskis University. This is an open-access article distributed under the terms of the Creative Commons Attribution License (CC-BY 4.0), which permits unrestricted use, distribution, and reproduction in any medium, provided the original author and source are credited. 


\section{THEORETICAL BACKGROUND}

Evaluation of company's propensity to be supported has been usually part of impact assessment of investment support programmes, especially studies using propensity score matching (Caliendo and Kopeinig, 2008; Khandker et al., 2010) as a statistical method based on a model of the probability of participating in the grant program, using observed characteristics (Michalek, 2012; Kirchweger et al., 2016). Empirical study from agriculture revealed that participating farms have been substantially larger, more capital and labour intensive than nonparticipating farms. They have also had lower indebtedness than nonparticipants before receiving support (Medonos et al., 2012; Ratinger et al., 2013). Empirical findings in the meat processing industry showed that participants were significantly larger, had higher profitability and slightly more bank loans than nonparticipants. Comparison of labour and capital intensity indicated that participants were more capital-intensive but less labour-intensive than nonparticipants (Spicka and Naglova, 2016).

Impact evaluation of subsidies in the food processing industry has been empirically studied and presented to policy makers (Harris and Trainor, 2005; Mezera and Spicka, 2013; Naglova et al., 2016; Spicka et al., 2017). Investment support increases investment activity and the size of supported companies. Simultaneously, investment support changes the capital structure of participants towards higher use of bank loans and positively affects long-term profitability. However, there were not any significant, positive effects on the intensity of the use of fixed assets and labour productivity, which has been a key impact indicator for programme evaluations.

\section{RESEARCH METHODS}

The company's propensity to be supported has been calculated through probit analysis (Medonos et al., 2012) or logit analysis (Kirchweger et al., 2016) on a set of structural and economic variables to calculate propensity scores (Rosenbaum and Rubin, 1983). In this article, probit model has been applied since it has been successfully tested in the Czech Rural Development Programme. A probit model is a type of regression where the dependent variable can take only two values, e.g. supported $(y=1)$ and not-supported unit $(y=0)$. The purpose of the model is to estimate the probability that an observation with particular characteristics (i.e. structural or economic feature of company) will fall into a specific one of the categories. Moreover, classifying observations based on their predicted probabilities is a type of binary classification model.

Let's suppose a response variable $\mathbf{y}$ is binary, that is it can have only two possible outcomes which we will denote as 1 and 0 . We also have a vector of regressors $\mathbf{x}$, which are assumed to influence the outcome $\mathbf{y}$. Specifically, we assume that the model takes the form

$$
\operatorname{Pr}(\mathbf{y}=1 \mid \mathbf{x})=\Phi\left(\mathrm{x}^{\mathrm{T}} \beta\right)
$$

where $\operatorname{Pr}$ denotes probability, and $\Phi$ is the Cumulative Distribution Function (CDF) of the standard normal distribution. The parameters $\beta$ are typically estimated by maximum likelihood.

Principal component analysis helped to select appropriate structural and economic variables from the original set of 66 variables. Principal components analysis is a data analysis tool used to reduce the dimensionality (number of variables) of a large number of interrelated variables, while retaining as much of the information (variation) as possible. It calculates an uncorrelated set of variables. Similarly, in regression analysis, the larger the number of explanatory variables allowed, the greater is the chance of overfitting the model, producing conclusions that fail to generalize to other datasets. One approach, especially when there are strong correlations between different possible explanatory variables, is to reduce them to a few principal components and then run the regression against them, a method called principal component regression. Author used a double-precision version of the modern QL algorithm as described by Press (Press, 1986) to solve the eigenvalue-eigenvector problem.

Propensity may be defined as an individual's probability of being treated with the intervention of interest given the complete set of all information about that individual. The propensity score provides a single metric that summarises all the information from explanatory variables such as size or profitability. An assumption of propensity score analysis is that a fair comparison of treatment outcomes can be made between subjects with similar propensity scores who either did or did not receive the treatment of interest. The propensity score for subject $i(i=1, \ldots, N)$ is defined as the conditional probability of assignment to a treatment $\left(Z_{i}=1\right)$ versus the control $\left(Z_{i}=0\right)$, given a set (or vector) of observed covariates, $\mathbf{x}_{\mathbf{i}}$. Mathematically, the propensity score for subject i can be expressed as

$$
e\left(\mathbf{x}_{i}\right)=\operatorname{pr}\left(Z_{i}=1 \mid \mathbf{X}_{i}=\mathbf{x}_{i}\right)
$$

It is assumed that the $Z_{\mathrm{i}}$ 's are independent, given the $\mathbf{X}$ 's. The observed covariates, $\mathbf{x}_{\mathbf{i}}$, are not necessarily the same covariates used in the matching algorithm, $\mathbf{y}_{\mathbf{i}}$, although they could be. Author used algorithm of propensity scores by Becker and Ichino (2002).

A difference of propensity score across branches of the food and beverage industry was tested through analysis of variance (ANOVA) and Scheffe test. ANOVA is a collection of statistical models and their associated procedures (such as "variation" among and between groups) used to analyze the differences among group means. The ANOVA tests the null hypothesis that samples in all groups are drawn from populations with the same mean values. To do this, two estimates are made of the population variance. These estimates rely on various assumptions: i) Response variable residuals are 
normally distributed (or approximately normally distributed), ii) Variances of populations are equal, iii) Responses for a given group are independent and identically distributed normal random variables. The ANOVA produces an F-statistic, the ratio of the variance calculated among the means to the variance within the samples. Bartlett's test verified equal variances. Kruskal-Wallis equality-of-populations rank test verified differences nonparametrically.

\section{DATA}

Database provided by the Ministry of Agriculture and the Ministry of Industry and Trade contains all supported companies from the food industry defined by NACE codes 10 and 11. To use structural and economic variables, database Bisnode MagnusWeb was used to get financial statements from supported and not supported companies. Year 2007 was selected as a reference year at the beginning of the programming period 2007-2013 because no companies were supported in this year. Databases from ministries and Bisnode were connected to get the most relevant database of structural and financial indicators of food processors (NACE 10) and beverage producers (NACE 11). Because sole holder holdings usually do not publish financial statements, the analysis is representative for small, medium and large corporations (legal entitites).

Original database was cleaned to remove unreliable data. Unreliable companies did not have any assets or revenues because they went bankrupt. Final database contained 1225 companies. However, not all indicators were available for all companies because some indicators could not be calculated due to zero denominator (e. g. companies they did not use bank loans). Final sample was 877 companies, of which 391 companies received subsidy and 486 didn't.

\section{RESULTS AND DISCUSSION}

PCA identified 12 factors representing $80.47 \%$ of variability of the original 66 variables. In the probit regression, however, we did not use the factors directly but the indicators they had a high correlation with the factors and at the same time they were materially the most suitable for analysis. Table 1 shows set of selected indicators and factors' focus. It is obvious that factors cover the most important structural and economic features of companies.

Table 1: Results of the PCA

\begin{tabular}{|l|l|l|}
\hline Factors & Indicators & $\begin{array}{l}\text { Cumulative } \\
\text { Percent }\end{array}$ \\
\hline F1: Company's size ('000 CZK) & Total Assets & 36.22 \\
\hline F2: Capital structure (\%) & Debt Ratio = (Debt / Total Assets) x 100 & 43.73 \\
\hline F3: Trade margin ('000 CZK) & Trade Margin = (Sales of Goods - Cost of Goods Sold) & 50.47 \\
\hline F4: Production margin (\%) & $\begin{array}{l}\text { Relative Gross Profit Margin = ((Sales of Products - Cost of Products Sold) / } \\
\text { Sales of Products) x 100 }\end{array}$ & 56.59 \\
\hline $\begin{array}{l}\text { F5: Working capital management } \\
\text { (\%) }\end{array}$ & $\begin{array}{l}\text { Working Capital Ratio (WCR) = Net Working Capital / Sales of Goods and } \\
\text { Products x 100 }\end{array}$ & 60.62 \\
\hline F6: Financial stability (\%) & Debt Service Coverage = EBIT / (Bank Loans + Interest Cost) x 100 & 64.23 \\
\hline F7: Liquidity (x) & Acid Test Ratio = (Current Assets - Inventory) / Current Liabilities & 67.74 \\
\hline F8: Labour Productivity (x) & Labour Productivity = (Sales of Products - Cost of Products Sold) / Staff Cost & 70.90 \\
\hline F9: Capital Equipment (x) & Capital Equipment = Tangible Assets / Staff Cost & 73.82 \\
\hline F10: Profitability (\%) & Return on Sales = (EBIT / Sales of Goods and Products) x 100 & 76.30 \\
\hline F11: Credit management (\%) & Credit Debt Ratio = (Bank Loans / Total Assets) x 100 & 78.49 \\
\hline F12: Asset Turnover (x) & Long-term Asset Turnover = Sales of Goods and Products / Long-term Assets & 80.47 \\
\hline
\end{tabular}

Source: author

Table 2 presents descriptive statistics of indicators grouped by participation in any of the grant programmes in the period 2008 - 2015 ( 1 = supported company, i.e. participant, 0 = not supported company, i.e. non-participant). Table 3 summarizes results of probit regression including standardized coefficients.

Table 2: Descriptive statistics of structural and economic indicators

\begin{tabular}{|c|c|c|c|c|c|}
\hline & \multirow[b]{2}{*}{ Label } & \multicolumn{2}{|c|}{ Participants (1) } & \multicolumn{2}{|c|}{ Non-participants $(0)$} \\
\hline & & Mean & $\begin{array}{c}\text { Standard } \\
\text { Deviation }\end{array}$ & Mean & $\begin{array}{c}\text { Standard } \\
\text { Deviation }\end{array}$ \\
\hline Total Assets ('000 CZK) & Assets & 227,865 & 962,228 & 110,227 & 466,896 \\
\hline Debt Ratio (\%) & DebtR & 62.855 & 44.546 & 83.74947 & 122.6475 \\
\hline Trade Margin ('000 CZK) & TrMgn & 12,397 & 46,328 & 17,396 & 120,444 \\
\hline Relative Gross Profit Margin (\%) & PrMgn & 4.237 & 343.289 & 8.134 & 172.630 \\
\hline Working Capital Ratio (\%) & WCR & 48.446 & 579.959 & -493.163 & 11771.951 \\
\hline Debt Service Coverage $(\%)$ & DSC & 38.061 & 347.364 & $1,303.556$ & $16,798.4$ \\
\hline Acid Test Ratio (x) & LiqL2 & 2.006 & 7.175 & 6.789 & 69.166 \\
\hline Labour Productivity (x) & LProd & 31.976 & 386.137 & 28.359 & 286.995 \\
\hline Capital Equipment (x) & CapEq & 289.747 & 2970.706 & 551.369 & 8439.539 \\
\hline Return on Sales $(\%)$ & ROS & 9.980 & 77.722 & 2.747 & 1071.835 \\
\hline Credit Debt Ratio (\%) & CrDR & 15.689 & 15.712 & 13.156 & 43.744 \\
\hline Long-term Asset Turnover (x) & AsTurn & 21.566 & 122.416 & 107.164 & 1325.578 \\
\hline
\end{tabular}

Source: author 
Table 3: Results of probit regression

\begin{tabular}{|c|c|c|c|}
\hline Indicator & Coef (SE) & $\mathrm{bStdX}$ & $\mathrm{bStdXY}$ \\
\hline Assets & $\begin{array}{c}0.0000 * * \\
(0.0000)\end{array}$ & 0.219 & 0.106 \\
\hline TrMgn & $\begin{array}{c}-0.0000^{* *} \\
(0.0000)\end{array}$ & -0.174 & -0.084 \\
\hline ROS & $\begin{array}{l}-0.0000 \\
(0.0001)\end{array}$ & -0.009 & -0.004 \\
\hline PrMgn & $\begin{array}{c}0.0003 \\
(0.0004) \\
\end{array}$ & 0.096 & 0.046 \\
\hline LiqL2 & $\begin{array}{c}-0.0620^{* *} \\
(0.0255) \\
\end{array}$ & -0.707 & -0.342 \\
\hline DSC & $\begin{array}{l}-0.0001 \\
(0.0001) \\
\end{array}$ & -1.509 & -0.731 \\
\hline DebtR & $\begin{array}{c}-0.0076 * * * \\
(0.0016)\end{array}$ & -0.371 & -0.180 \\
\hline CrDR & $\begin{array}{c}0.0047 * * \\
(0.0022)\end{array}$ & 0.114 & 0.055 \\
\hline CapEq & $\begin{array}{l}-0.0000 \\
(0.0000)\end{array}$ & -0.062 & -0.030 \\
\hline AsTurn & $\begin{array}{l}-0.0003 \\
(0.0002)\end{array}$ & -0.351 & -0.170 \\
\hline LProd & $\begin{array}{c}0.0001 \\
(0.0001)\end{array}$ & 0.023 & 0.011 \\
\hline WCR & $\begin{array}{c}0.0003 \\
(0.0002) \\
\end{array}$ & 0.534 & 0.259 \\
\hline Constant & $\begin{array}{c}0.3866 * * * \\
(0.1232)\end{array}$ & $\mathrm{x}$ & $\mathrm{x}$ \\
\hline $\begin{array}{l}\mathrm{N}=877 \\
\mathrm{LR} \chi^{2}(12)=66.48 \\
\text { Prob }>\chi^{2}=0.0000 \\
\text { Log likelihood }=-569.49632 \\
\text { Pseudo } \mathrm{R}^{2}=0.0551\end{array}$ & & & \\
\hline
\end{tabular}

Notes: Standard errors in parentheses, *** $\mathrm{p}<0.01, * * \mathrm{p}<0.05, * \mathrm{p}<0.1$,

$\mathrm{bStdX}=\mathrm{x}$-standardized coefficient, $\mathrm{bStdXY}=$ fully standardized coefficient

Source: author

Probit regression shows that total assets, trade margin, liquidity, debt ratio and credit debt ratio are significant variables affecting propensity to be supported. So, size, trade margin, liquidity and capital structure significantly determine participation of food processors in development programmes. Participants are substantially larger than nonparticipants which does not correspond to the previous findings (Medonos et al., 2012). However, size of farms was measured by utilized agricultural area per farm whereas size of food processors was expressed by total assets. Later research showed significantly large participants than nonparticipants measured through total assets, revenues (Ratinger et al., 2013) and output (Kirchweger and Kantelhardt, 2015). Standardized coefficient bStdX 0.219 means that 1 standard deviation increase in total assets (' $000 \mathrm{CZK}$ ) produces, on average, a 0.219 increase in the log odds of being supported.

Trade margin is a difference between sales of goods and cost of goods sold. Companies which have zero trade margin just produce food or beverages. Alternatively, companies with positive trade margin either trade with products made by other food processors or have their own company store. Participants had lower trade margin than nonparticipants. Results cannot be compared with previous studies.

Liquidity L2 (Acid Test Ratio) is higher in the group of non-participants (6.789) than participants (2.006). Interpretation is not so clear how it seems because too high liquidity indicates poor short-term financial management. Such companies use excessive amount of current assets which could be used more efficiently. Alternatively, mean value of liquidity in the group of participants is closer to recommended interval for Acid Test Ratio 1.0 - 1.5 (Gibson, 2013 ). Results indicate that participants manage current assets and liquidity better than non-participanting companies. Standardized coefficient bStdX -0.707 means that 1 standard deviation increase in liquidity produces, on average, a 0.707 decrease in the log odds of being supported.

Debt ratio is the only one statistically significant indicator at $\alpha=0.01$. Results of probit regression came up to expectation that nonparticipants had significantly higher debt ratio than supported companies. High indebtedness is aggravating factor when applying for investment support. Moreover, mean debt ratio higher than $80 \%$ shows problems with financial management. Results follow previous findings from agriculture (Ratinger et al., 2013). Standardized coefficient bStdX -0.371 means that 1 standard deviation increase in debt ratio produces, on average, a 0.371 decrease in the log odds of being supported.

Because applicants often ask for credit to co-finance investment projects, they should have better experience with credit management. So, the use of credit is significant determinant of being supported. Participating companies had higher credit debt ratio than nonparticipating companies. The result make sense because one reason why nonparticipants weren't supported is their bad financial condition and difficult access to credit. Standardized coefficient bStdX 0.114 means that 
1 standard deviation increase in credit debt ratio produces, on average, a 0.114 increase in the log odds of being supported. However, too high credit debt ratio can increase debt ratio and reduce chance to be supported as it was concluded above. The results correspond to the previous results from agriculture (Ratinger et al., 2013).

The distribution of estimated propensity scores is illustrated in Figure 5. A good overlap is evident.

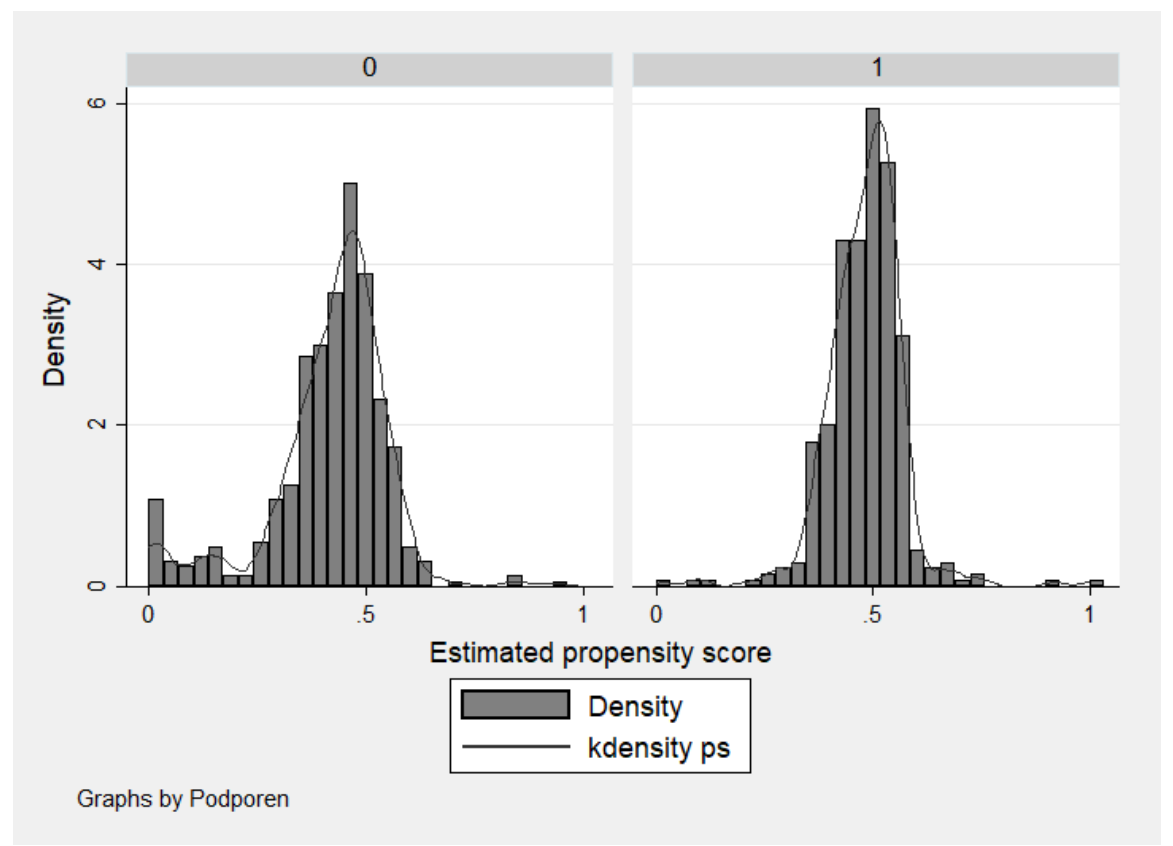

Source: author

Figure 1. Distribution of propensity scores of participation of food processors in the Czech Republic

When comparing propensity scores across branches of the food and beverage industry (NACE 10 and 11), it is evident that there are differences between branches (table 4).

Table 4: Results of ANOVA

\begin{tabular}{|c|c|c|c|c|c|}
\hline Source & SS & df & MS & $\mathrm{F}$ & Prob > F \\
\hline Between groups & 0.5663 & 9 & 0.0629 & \multirow[t]{3}{*}{4.30} & \multirow[t]{3}{*}{0.0000} \\
\hline Within groups & 12.6949 & 867 & 0.0146 & & \\
\hline Total & 13.2612 & 876 & 0.0151 & & \\
\hline \multicolumn{6}{|c|}{ Bartlett's test for equal variances: $\operatorname{chi} 2(9)=62.9974$ Prob $>$ chi $2=0.000$} \\
\hline \multicolumn{6}{|c|}{$\begin{array}{l}\text { Kruskal-Wallis equality-of-populations rank test } \\
\text { chi-squared }=41.609(\mathrm{p} \text {-value }=0.0001)\end{array}$} \\
\hline
\end{tabular}

Scheffe test revealed that NACE 10.4 is significantly different from other branches. Companies processing vegetable and animal oils and fats has significantly lower propensity score to be supported. The problem is that it is very specific branch. It is highly concentrated industry dominated by large companies which strong capital power and low need to be supported from public funds. They use its own capital or bank loans for modernization and innovation. Alternatively, Scheffe test did not indicate significant differences between other branches than 10.4. It is required as all branches should have the same chance to be supported.

\section{CONCLUSION}

The aim of the article was to quantify differences in structural and economic indicators between participants and nonparticipants of the investment support programmes in the Czech food industry in year at the beginning of the "old" programming period (2007). Companies with larger size (total assets), lower trade margin, optimal liquidity, lower debt ratio and higher credit debt ratio had higher propensity to be supported. Except absolute indicators like trade margin and total assets, all relative indicators have been evaluated when companies apply for grants in the Czech Rural Development Programme.

From the political point of view, particularly interesting finding was about the size of companies. Fact that larger had higher chance to be supported goes against declaration of equal chances for all sizes of companies. In recent years, grant programs have focused especially on small companies. It is in compliance with higher credit debt ratio of supported companies as small companies usually do not have such easy access to credit as larger companies.

In the current programming period 2014+, Ministry of Agriculture and Ministry of Industry and Trade have improved system of project selection to consider more efficiency and effectiveness. Moreover, they improved advisory services to provide all applicants reliable information how to manage application. Finally, policy makers decided to keep financial status as selection criterion in the current programming period to prevent programme from bankrupt companies. 


\section{ACKNOWLEDGEMENT}

The paper was supported by the Internal Grant Agency of the University of Economics, Prague, project "The impact of support for public investment projects on the gross added value of supported enterprises", No. F3/46/2017.

\section{REFERENCES}

1. Ascione, E., Cristiano, S., Tarangioli, S. 2011. Farm Advisory Services for the Agro-Food Supply Chain as a Foster of Innovation: The Case of Veneto Region. Proceedings in Food System Dynamics, Proceedings in System Dynamics and Innovation in Food Networks, pp. 447-461.

2. Becker, S.O., Ichino, A. 2002. Estimation of Average Treatment Effects Based on Propensity Scores. The Stata Journal, Vol. 2 , pp. 358-377.

3. Caliendo, M., Kopeinig, S. 2008. Some Practical Guidance for the Implementation of Propensity Score Matching. Journal of Economic Surveys, Vol. 22, pp. 31-72. https://doi.org/10.1111/j.1467-6419.2007.00527.x

4. Gibson, C.H. 2013. Financial Statement Analysis, 13 ${ }^{\text {th }}$ edition, international edition ed., South-Western; Cengage Learning [distributor], Mason, Ohio.

5. Harris, R., Trainor, M. 2005. Capital Subsidies and their Impact on Total Factor Productivity: Firm-Level Evidence from Northern Ireland. Journal of Regional Science, Vol. 45, pp. 49-74. https://doi.org/10.1111/j.0022-4146.2005.00364.X

6. Hodrab, R., Maitah, M., Smutka, L. 2016. The Effect of Information and Communication Technology on Economic Growth: Arab World Case. International Journal of Economics and Financial, Iss. 6, pp. 765-775.

7. Khandker, S.R., Koolwal, G.B., Samad, H.A. 2010. Handbook on Impact Evaluation: Quantitative Methods and Practices, World Bank, Washington, D.C.

8. Kirchweger, S., Kantelhardt, J. 2015. The Dynamic Effects of Government-supported Farm-investment activities on Structural Change in Austrian Agriculture. Land Use Policy, Vol. 48, pp. 73-93. https://doi.org/10.1016/j.landusepol.2015.05.005

9. Kirchweger, S., Kantelhardt, J., Leisch, F. 2016. Impacts of the Government-supported Investments on the Economic Farm Performance in Austria. Agricultural Economics - Zemedelska ekonomika, No. 61, pp. 343-355.

10. Kontsevaya, S., Alborov, R., Kontsevaya, S., Kontsevoy, G. 2016. Estimation of Current Status of Internal Economic Control in Russian Agriculture. Economic Science for Rural Development: New Dimensions in the Development of Society Marketing And Sustainable Consumption Finance and Taxes, Vol. 43, pp. 290-295, Latvia University of Agriculture, Jelgava.

11. Medonos, T., Ratinger, T., Hruska, M., Spicka, J. 2012. The Assessment of the Effects of Investment Support Measures of the Rural Development Programmes: The Case of the Czech Republic. Agris on-line Papers in Economics and Informatics, Vol. 4, pp. 35-48.

12. Mezera, J., Spicka, J. 2013. Economic Effects of Investment Support of Adding Value to Food Products. Agris on-line Papers in Economics and Informatics, Vol. 5, pp. 39-49.

13. Michalek, J. 2012. Counterfactual impact Evaluation of EU Rural Development Programmes: Propensity Score Matching Methodology Applied to Selected EU Member States. Volume 1: A micro-level approach. Publications Office; FAO, Luxembourg, Rome.

14. Naglova, Z., Boberova, B., Horakova, T., Smutka, L. 2017. Statistical analysis of factors influencing the results of enterprises in dairy industry. Agricultural Economics-Zemedelska ekonomika, No. 63, pp. 259-270.

15. Naglova, Z., Spicka, J., Gurtler, M. 2016. Evaluation of Effects of Investment Support in the Czech Dairy Industry. Acta Universitatis Agriculturae et Silviculturae Mendelianae Brunensis, Vol. 64, pp. $1345-1351$. https://doi.org/10.11118/actaun201664041345

16. Press, W. H. 1986. Numerical Recipes. Cambridge University Press, New York.

17. Ratinger, T., Medonos, T., Hruska, M. 2013. An Assessment of the Differentiated Effects of the Investment Support to Agricultural Modernisation: the Case of the Czech Republic. Agris on-line Papers in Economics and Informatics, Vol. 5, pp. 153-164.

18. Rosenbaum, P.R., Rubin, D.B. 1983. The Central Role of the Propensity Score in Observational Studies for Causal Effects. Biometrika, Vol. 70, pp. 41-55. https://doi.org/10.1093/biomet/70.1.41

19. Spicka, J., Naglova, Z. 2016. Distribution of the Investment Subsidies in The Czech Meat Processing Industry. Proceedings of the International Scientific Conference "Agrarian Perspectives XXV: Global and European Challenges for Food Production, Agribusiness and the Rural Economy”, pp. 384-391, Czech University of Life Sciences, Prague.

20. Spicka, J., Naglova, Z., Gurtler, M. 2017. Effects of The Investment Support In The Czech Meat Processing Industry. Agricultural Economics-Zemedelska ekonomika, No. 63, pp. 356-369. 